\title{
ROLE OF STATE AND WELFARE STATE: FROM COMMONS, KEYNES TO ESPING-ANDERSEN
}

\author{
Wisnu Setiadi Nugroho \\ Department of Economics, Colorado State University \\ Fakultas Ekonomika dan Bisnis, Universitas Gadjah Mada \\ Jl. Sosio Humaniora No. 1, Bulaksumur, Depok, Sleman, Daerah Istimewa Yogyakarta 55281 \\ Correspondence E-mail: wisnu.nugroho@ugm.ac.id \\ Received: August 2018; Accepted: October 2018
}

\begin{abstract}
The welfare state system is a popular economic system nowadays. At least more than fifteen countries have the characteristics of a welfare state economic system with their respective character and features. Esping-Andersen divided the welfare system classification into three major groups, namely the conservative welfare state, socio-democratic welfare state, and liberal welfare state. This article attempts to link the idea and foundation of a welfare state system is two utmost significant economists, John Maynard Keynes and John Roger Commons. Based on history of economic thought, Keynes's thought about the system of welfare states can be seen and traced in the liberal welfare state system on EspingAndersen classification. On the other hand, traces of Commons' thought can be seen in the socio-democratic state welfare system. Therefore, both Keynes and Commons can be categorized as the founding fathers of the welfare state system. Since their thought about the role of the state is the foundation of welfare state system, long before the United Kingdom began implementing the modern welfare state system in the 1980s. In addition, this study also attempts to undertake comparative analysis of economic systems and present the empirical data on the performance of welfare countries based Esping-Andersen classification in three categories: economic performance, quality $\mathcal{E}$ health performance, and level of accumulation of human resources. It is hoped that with the facts presented here there will be further discussion regarding the welfare state system.

Keywords: John Maynard Keynes, John Roger Commons, Welfare State System, History of Economic Thought, Comparative Analysis of Economic Systems.
\end{abstract}

JEL Classifications: P51, B25, B30, B52, P47

\section{INTRODUCTION}

Keynes perspective on government role and intervention in the economy is a foundation of the development of the role of the state. While classical economics relies on laissez-faire and free market with fewer government roles or intervention, Keynes sees that government needs to be involved more in the economy. Keynes' believes that government is the last pillar to support the economy when the consumer spending, the investment, and the export are failing. Keynes in favor of holding the State accountable to the taxpayer for the goods and services provided, however, he is against high tax- es on an employee to provide a social benefit (Marcuzzo, 2005).

Years before Keynes promoted government intervention in the economy; John Commons (1924) had already emphasized the importance of the role of the state. Keynes's and Common's share similar perspective in politics, economic policy and social progress (Thabet, 2008). In economic policy, both Keynes and Commons is a proponent of a government role in providing goods and services. While, from the perspective of social progress, Keynes and Commons influenced by Dewey "New Liberalism" (Thabet, 2008). Commons even mentions 
in his book that he is "Last Mohican of Liberalism" through institutional economics (Commons, Myself, 1963) ${ }^{1}$.

However, although both have a lot of similarities, Keynes and Commons have difference in several aspects such government roles and intervention. While Keynes believes that government intervention is only needed when the market fails to perform and deliver, Commons thinks that government intervention should be an essential component in the economy at the very beginning. Another significant difference between Keynes and Commons is how they believe about the taxes. While Keynes is against tax levies on the employee to provide social benefit, Commons is a proponent of the tax system that can redistribute the wealth and create social benefit for the worker. Thus, it could be seen that Keynes is a proponent of passive government roles, while Commons is a proponent of active-conservative government roles ${ }^{2}$.

Commons (1924) emphasized that government need to be involved in the economy to create fair a transaction environment. The government roles in the transaction, for example, is by becoming a mediator between parties as well as reduces conflict within people in the state which would ultimately increase the general well-being of the society. In economy, Commons introduced the term of the FifthParty transaction. The fifth party is an arbitrator that assures that there is no discrimination or violation of working rules. The fifth party could be a judge, priest, foreman, superintendent or government officials that can settle a dispute between parties. In the case of the role of the state, Commons emphasized that a state play a vital role as the fifth-party in the economy specifically in term of the transaction.

\footnotetext{
1 Which also can be found in Thalbet, 2008.

2 Passive government roles is defined as the government does not intervene in the market because it believes that the more government intervention in the market, the less freedom a market has. In the opposite, active government roles tend to intervene the market. Keeping active conservative means that government does intervene the market but on specific limitation.
}

Furthermore, there are three roots of dispute in the transaction that Commons (1924) emphasize become the reason that government/state should play the role of the fifth party. They are performance, avoidance, and forbearance (Commons, 1924). The performance problem is explained by the liberty act not to act. For example, seller and buyers in eBay agree on a trade of goods. However, after the buyer makes the payment and seller sent the item, the buyer finds the item is not as mentioned in the listing. Thus, the buyer needs to settle the case with the help of another party, which in this case is an eBay customer service. In a similar situation, if a buyer and seller agree on a trade, and the buyer chooses not pay for the item, then it becomes an avoidance problem. The last problem, forbearer, could be explained in a similar situation. A person (for example a buyer) could exert some pressure on the seller to fulfill its obligation. However, the buyer is being prohibited from crossing a certain point by a duty of forbearance. In this case, the role of the fifth party or state becomes very important, since the fifth party can legally exert rules for both parties.

We can find Commons definition of the role of the state in modern welfare state principles. Although rarely mentioning Commons, the foundation, principles, and characteristics of the current Welfare State, especially conservative-corporatist welfare state system, are quite similar to Commons definition of the role of the state. We also try to find a connection between Keynes the role of the state with the EspingAndersen liberal welfare state. In this paper, we will discuss how current welfare state defined by Esping-Andersen welfare state classification is related to Commons and Keynes role of the state.

\section{RESEARCH METHOD}

The state defined by territorial region governed by the sovereign body. A state itself is different from a nation, whereas a nation is a 
group of people who see themselves as a cohesive and coherent unit based on shared cultural or historical criteria (Flint, 2012). Flint (2012) also mentions several characteristics of state:

1. A state is a territory: has a clear border, recognized by another country, sovereign of state has control over the territory and defend within the borders.

2. States have bureaucracies: state staffed by government personnel.

3. State monopolies specific functions within its territory: control the legitimate use of force, money circulation, makes rules and law, and control information within the state.

The third characteristic above mentioned is explicitly talking about the role of the state. We will continue discussing the role of the state in Commons perspective and welfare state view on this paper.

\section{RESULTS AND DISCUSSION}

\section{John Commons Role of State}

Commons conception on the role of the state divided into three primary processes (Chase, 1986): First, the incentive to create the state by collective effort to control the use of violence. Motivation to create the state happens when authorities enforce rights and duties to everyone. By imposing rights and duties violence and conflict among people who lived together as a community could be reduced. Commons argues that human is naturally considering violence in the most cases is necessary. Violence is usually needed because of scarcity notion and the possibility of a conflict of interest with passion biased (Chase, 1986).

Second, the process of liberating and expanding the power of the people while also enforcing a distribution of liberty and property. There is a broad definition of the interpretation of liberty. It could be free to act and conducting a transaction without any pressure and exploitation, and it is also could be free from the dependency of the economic scarcity of goods and services which creates unbalanced economic power in the transaction. In general, liberty means civil liberty Commons perspective (Commons, 1924 p.150). Distributing of property means that the state should make sure that property distributed equally among people to support the production process. Property in general consists of stocks of physical things owned exclusively for an individual. Gonce (1971) also notes that Commons concept of the state is where state built to protect private ownership. Commons using the term "Rationing Transaction" to talk about wealth distribution. The term is similar to the contemporary world when government levies taxes and rationing the national wealth among citizen.

Third and the last primary process of defining state is by determines the effective rules for a public purpose. The state must enact policies and regulations that fair for all. Every policies and transaction of the state through official affects the distribution of wealth, liberty, and rights of every individual. Make sure that there is no exploitation from one party to another party since one person's right is another person's duty, vice versa. Fair working rules ultimately will improve the economy. With the distributive role of the state, the equal economy pie will eventually lead to the improvement of the general well-being of all individuals.

These three processes are defining Commons' role of the state. The three processes can be summarized by a specific role such as reduce conflicts, harnessing the violence and enforcing duties which liberate and expand powers of an individual while also providing a security expectation. Commons also viewed that state as mediation of competing on different interest, solving problems and developing reasonable value in a democratic society (Waller in Pressman, 2006). Commons also argues that the state should not let free competition determined the equilibrium outcome in the market. Commons explains that free competition is creating wastefulness, low ethical standard, low wages, dan- 
gerous working condition and monopoly (Gonce, 1971). Commons also notes that the government should not own a state-owned firm if it not needed since government mostly enacts the regulation and policies. Commons argues it will not be fair and has a possibility creates conflict between a state with the private firm if government involvement in the economy through the state-ownership unneeded company.

Commons role of state could be identified lies between in the middle of full control and laissez-faire. Commons evolutionism also believed that government needs to be flexible and dynamic enough to respond to the changes happened in the society. The government could be asserting more or less control depending on the needs and how society develops during that era. Todays' role of the state defined by Commons is substantially similar to the current definition of the welfare state. Harris (1952) mentions that Commons institutional economics sets the principles and methods which become the foundation of the welfare state.

\section{Keynes Role of State}

Keynes, the role of the state, could be traced back to his work Essay in Persuasion, explicitly in the article of The End of Laissez Faire. Peacock (1991) notes that Keynes gives a solution to reach the realization of full employment by the limited expansion of the role of the state through fiscal policy. Peacock (1991) emphasize that Keynes position on the role of the state is distant from collectivism socialism.

Keynes (2010) mentions that the ideal size for a unit of control and organization is between the individual and modern state. Keynes (2010) argues that state should interfere if corporation unable to deliver the goods and services. For example, the case of public goods such the road or street light. From the perspective of cost and benefit analysis, it is costly to provide kind of goods. Based on the comment, we can conclude that Keynes believes in the public goods provision from the state. Thus, to provide these goods, the government needs to do the intervention in the market.

In the term of public goods, Keynes argues that 'Government in a democracy should ... do those thing which at present are not done at all' (Chandavarkar, 1911 p.164).

Michael Lipton also comments on Chandavarkar (1991) articles '[Keynes] show that he would not have accepted that states should provide all or only public goods ... Many of these can readily be produced, provided, and/or financed by the private sector, under contract or otherwise - e.g., some sorts of agricultural research. On the other hand, many private (priceable, rivalrous) goods, e.g., drinking water, are natural monopolies; they require either public provision or public regulation, and public provision-with-production may be the best" (Chardavarkar 1991, p.164).

Table 1. Keynes' versus. Commons' Role of the State

\begin{tabular}{|c|c|}
\hline Keynes & Commons \\
\hline 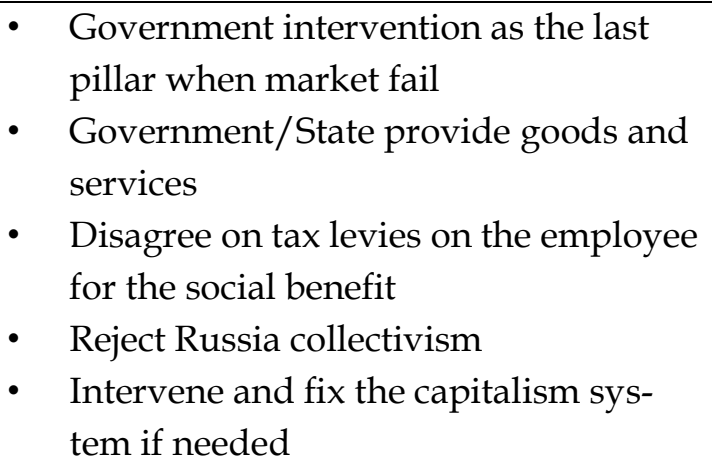 & $\begin{array}{l}\text { - } \begin{array}{l}\text { Government playing an active- } \\
\text { conservative role in the economy }\end{array} \\
\text { - Government/State provide goods and } \\
\text { services } \\
\text { - Agree on tax for social benefit (redistri- } \\
\text { bution of wealth) } \\
\text { - Reject Russia collectivism } \\
\text { Regulate capitalism, not destroy the sys- } \\
\text { tem }\end{array}$ \\
\hline
\end{tabular}

Source: Author, Summarized from Different Books and Article (Modified). 
Lipton also comments that the state should not nationalize an industry if the purpose of it is commercial rather than solving market failure (Chardavakar, 1991). Keynes (2010) also emphasize that a firm should not be too big to avoid domination in the market and unproductive capital. Domination in the market will create a monopoly which unhealthy in term of growth and production. Unproductive capital is when the firm is so big. Thus, they can earn money by only investing the money without creating the value of activity or productivity. In modern day, we can see Keynes prediction during the 2008 financial crisis. A lot of big financial firm is collapse after years of years utilizing capital as "money making" tools instead of investing it in the productivity sector.

Keynes has similar principles with Commons on the role of the state. Keynes emphasize on "too big" for the firm is identical to Commons focus on government as a fifth-party transaction. Both of them essentially says that the government should do an intervention to create a fair environment for the transaction in the market. As we discussed above, the significant differences between Keynes and Commons role of the state are how far government should intervene the market. While Commons emphasize that government should be in the market since day one, Keynes believes government needs to intervene the market when needed with limited capacity. Later, in this paper, we will discuss how Commons and Keynes role of the state is the foundation and principles of the welfare state.

In summary, the difference and similarities role of the state between Keynes and Commons can be seen in the table 1 .

\section{The Welfare State}

Modern-day welfare state could be traced back to Britain after the second world-war (Johnson, 1987 p.3). However, few decades before that Germany had already conducting policy such sickness insurance and old-age pensions which similar to welfare state policy in the modern day. Barr (2004) in Marcuzzo (2005) notes that welfare state is the role of state on four different areas: cash benefits or cash transfer; universal health care; primary education; and food, housing, and other welfare services.

Esping-Andersen notes that two approaches are dominating of welfare state explanation. First, the systems or structuralism approach which emphasis on the structures and whole systems. This approach focus on the laws of motion of systems. This approach argues that the welfare state is possible because of the rise of modern bureaucracy as a form of rational, universal and efficient organization. The second approach is the institutional approach, which emphasizes how democratic institution influences the development of the welfare state. Esping-Andersen mentions that the institutional approach insists that separating economy with the social and political institution will disturbing the society. Based on this approach, the economy is embedded in the social communities as an institution to survive. For example, workers in the factory demanding a social wage, while farmers demand that the state protect them from international competition by enacting tariff and gives subsidy.

This approach is where John Commons left his legacy. As mentioned above, Commons emphasis that state is playing the role as a social and political institution in the society. The state needs to be involved as fifth-party in the transaction, while also serves as a policymaker, a protector, and liberator for its citizen. For example, the government implement tax policy gives free education and enacting universal health insurance system to serve as a social and political institution. This government role mentioned by Commons align with an institutional approach which defined the welfare state.

Further discussion about Welfare State started when Esping-Andersen introduced the three different system of the modern welfare 
state in 1990. Current welfare state itself built on four pillars ${ }^{3}$ :

1. Compulsory and Primary education: Free primary education and heavily subsidized higher education such as college and university.

2. Universal health treatment: Collective contribution of health cost or heavily subsidized comprehensive health insurance.

3. Social security and pensions: Worker pensions and life insurances which collected during the working period of individuals and become a safety net for old days or catastrophic event.

4. Social Services: Different kind of aid type ranging from the tax credit to universal basic income.

These main pillars then divide the type into several types of welfare state. Esping-Andersen looks in two dimensions to determine different welfare state systems (Cochrane, 2001, p.13):

1. The degree of labor de-commodification "The degree to which individuals, or families, can uphold a socially acceptable standard of living independently of market participation' (i.e., without paid employment) (Esping-Andersen, 1990, p.37)".

2. Degree of stratification

"The degree to which individuals the welfare state differentials between social groups (for example by occupational status)".

Esping-Andersen using this two dimension to divide welfare state systems or models into three categories; social democratic, conservative, and liberal (Esping-Andersen, 1990). Social democratic model type countries such as Denmark, Norway, Iceland, Finland, and Sweden. Conservative model type countries such as Germany, Netherlands, Spain, Italy, Belgium, Austria, etc. Liberal model type countries such as the United Kingdom, United States, Ireland,

${ }^{3}$ Cited at http://www.learneurope.eu/index.php?clD=300 accessed November $3^{\text {rd }}, 2017$ and Luxemburg4. Most of the states are committed to their model and system. The only exception is for Ireland, which switches their system from conservative to liberal recently.

\subsection{Conservative Welfare State}

German welfare system is considered as conservative-corporate model welfare state system in Esping-Andersen typology (Cochrane et al., 2001 p.154). The distinctive feature of this model is the existence of a welfare program and government roles on social policies. Welfare program with the primary purpose of income maintenance of individuals or families within the state. Programs such as affordable social insurance, social assistance for families, and plan for pensions and social security are notable distinctive features in this model of the welfare state.

Cochrane et al. (2001) state five fundamental organizing principles of the conservative welfare state:

1. Welfare Regime: Assistance is employment centered, and universal social insurance is obligatory.

2. Corporatist Welfare Regime: Policymaking, administrative process and delivery of welfare with incorporation from the interest of the various group. This inclusion of interest also means coalition building needed to maintain social stability.

3. The principle of subsidiarity: Relied on Catholic social ethics were family as the "first resort" provider. It means if the family can do it, the government should not intervene. This principle also says that the administrative responsibility and the decision making will be a shift to the lowest level.

4. Patriarchal: Male as breadwinner and female as the leading providers of informal welfare.
${ }^{4}$ Cited at http://www.learneurope.eu/index.php?clD=300 accessed November 3 rd, 2017 
5. Exclusive conceptualization: Citizenship status is needed to receive welfare assistance.

Align with Commons role of state discussion; this system is the closest to Commons' role of the state. However, there are several notable differences between the conservative welfare state systems with Commons' idea of the role of the state. One of them is the patriarchal system and how people divided into several groups of classes. In Commons thought, individual should not be divided into classes because everyone should be equal. Commons also would not agree about gender biased between male and female. His opinion of social justice defines that there should be no difference in treatment between male and female.

\subsection{Social Democratic State}

The social democratic state system is a deviation from conservative welfare state with more roles of government. An excellent example of the country adopting this system in Sweden. Thus, many people mention social democratic state system is the Swedish system. The most notable feature of this system is high spending on national income on welfare benefits and services. High expenditures imply a public provision, universal accessibility on health and education, and more top participation of individuals in the government from Election Day to how should the government do their policies. The primary focus of the social democratic system is mitigating class difference and reducing gender equality. Market income for countries adopting this system usually unequal, however after taxes and benefits from government disposable income tend to more equally distributed in this system rather than conservative system (ex: Germany) and liberal system (ex: UK/USA) (Cochrane et al., 2001 p200).

\subsection{Liberal Welfare State}

Another deviation from conservative-corporatist welfare state system is The Liberal Wel- fare State system. This system is pretty similar to what Keynes defined about the role of the state. We can find the liberal state welfare state in the modern day the UK. Esping-Andersen identified that characteristics of this system are minimum private welfare schemes, modest welfare transfer, and social-insurance plan. The system also encourages liberal work-ethic norm which determines welfare as an option. If people choose not to receive it and can work hard to fulfill his needs, then the government should not force to help them through welfare transfer.

The next characteristics of this system are that the state encourages the market to provide the goods and services. It leads to small de-commodification effect and makes an order of stratification exist. Order of stratification exists due to poverty or inequality within society. In the liberal market, we can see that there is a market differentiation between majorities and minorities or between the rich and the poor. For example, hospital as representative of the market for health in the liberal market conducts differentiation on their services and facilities. There will be differentiations on the services, the medicine quality, the infirmary quality, doctor and nurse care and much more based on how much people can pay or which class services that people choose. As we can see here, liberal welfare state characteristics are substantially similar to what Keynes emphasizes on the role of the state. Liberal welfare state system is limiting their intervention in the market while keep maintaining and monitoring the market conduct and fairness. State intervention limitation in the market mainly what Keynes proposes as the role of the state? This study can also see that the liberal welfare state system still provides public goods such as health and education. This public goods provision is what Keynes says about how the state should do about public goods. Since if this study let the market determine the supply of these goods (education and health), it could become an inadequate supply of the goods or it could be unaffordable for most people. Thus, 
the state needs to play a role in providing these public goods.

\section{A Little Glance at Empirical Data}

\subsubsection{Economic Performance}

Three different data on economic performance are used: GDP per capita (PPP base on 2011), total unemployment rate and domestic price volatility. Based on GDP, liberal welfare state performs well on average, while social-democratic come second and conservative welfare state come last. However, the graph also shows that social democratic welfare states have a huge GDP gap between Norway and the rest of social democratic states (Sweden, Finland, Iceland, and Denmark).

Figure 1. Gross Domestic Product per Capita (2011 PPP USD) ${ }^{5}$

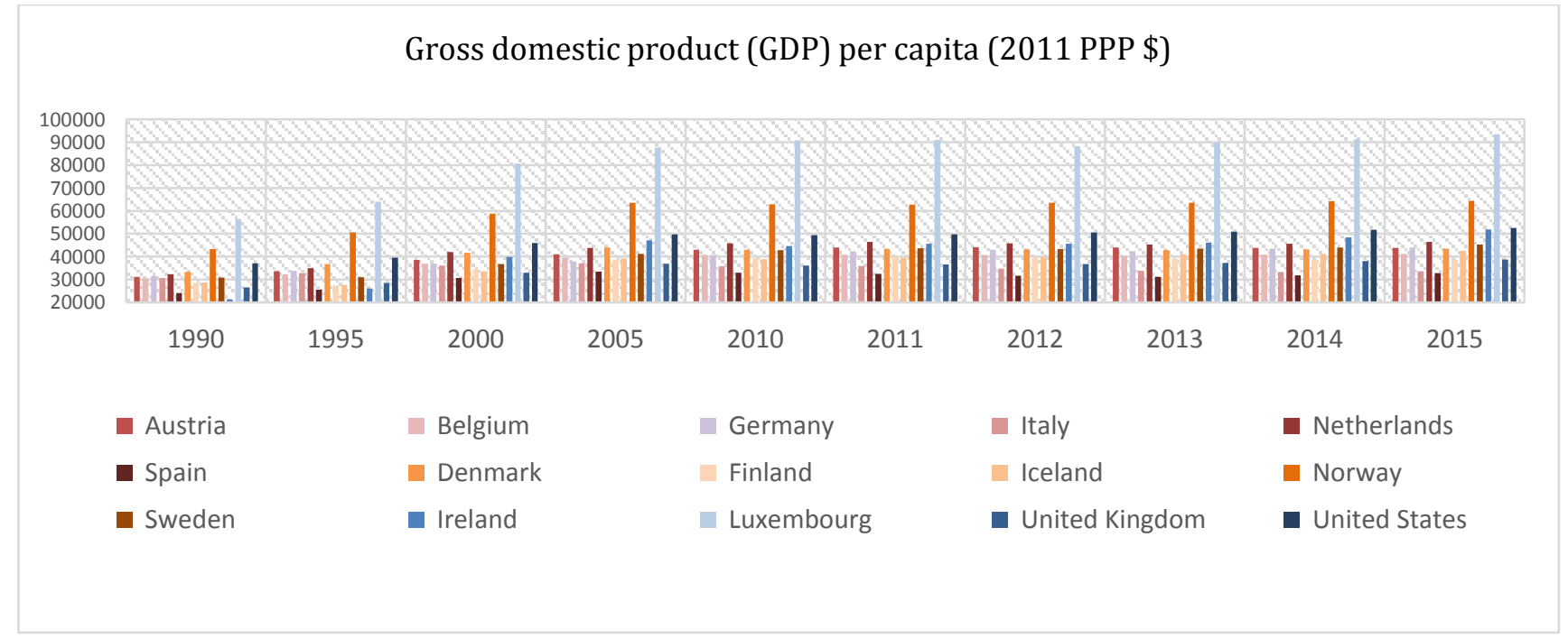

Source: Human Development Data, UNDP $2016^{6}$

Figure 2. Total Unemployment Rate (Percent of Labor Force)

Total unemployment rate (\% of labor force)

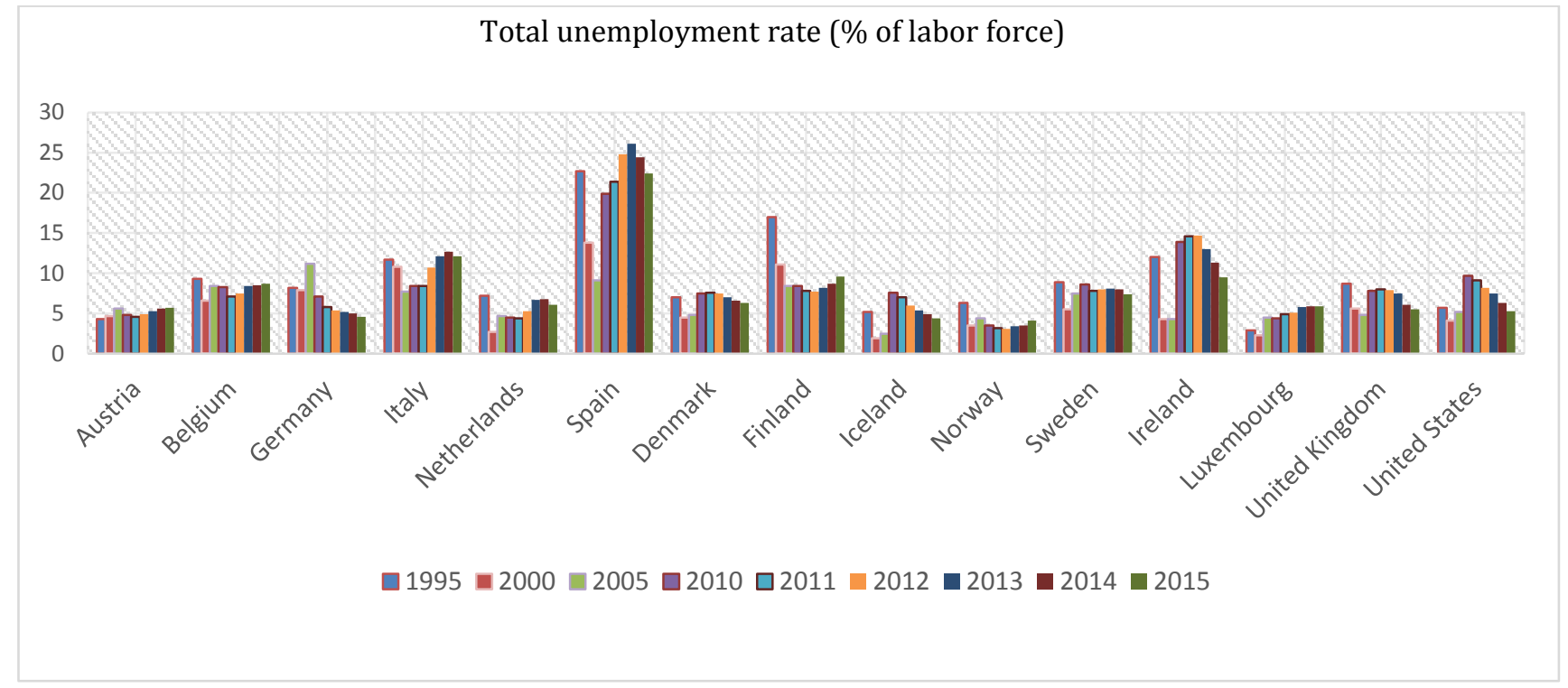

Source: Human Development Data, UNDP 2016.

\footnotetext{
5 Red color is representing countries with conservative welfare state, green is Social-Democratic Welfare State, and blue is Liberal welfare state. This applies to all figures and graphs

${ }^{6}$ Can be downloaded at http://hdr.undp.org/en/data\#
} 
Although it comes last, conservative welfare state tends to be similar to each other or clustered around the mean. As shown in figure 1.

Based on the total unemployment rate, social democratic welfare state on average perform the best (except Finland), liberal welfare states come second (exception of Ireland), and the conservative welfare states come last. Once again, although come last between three-welfare state systems, conservative welfare states tend to have similar mean. There are not so many variances of total unemployment between these states rather than another system (social democratic and liberal system). As shown in figure 2 .

The third economic indicator is domestic price volatility. In this indicator, the liberal wel- fare state system come on top, conservative come second and social democratic come last. Even, liberal welfare state such US does not have a record of domestic price volatility since there is only limited price volatility happened. This fact is interesting since as state put more control of the market goods and services, the more volatile is the market. It is like market actors have the incentive to speculate in the market when they know that the government will do some intervention, later on, to make sure the volatility does not exceed the expectation.

Further research needs to be done to see this problem thoroughly. We can see the domestic price volatility in figure 3 .

\section{Figure 3. Domestic Food Price Volatility Index}

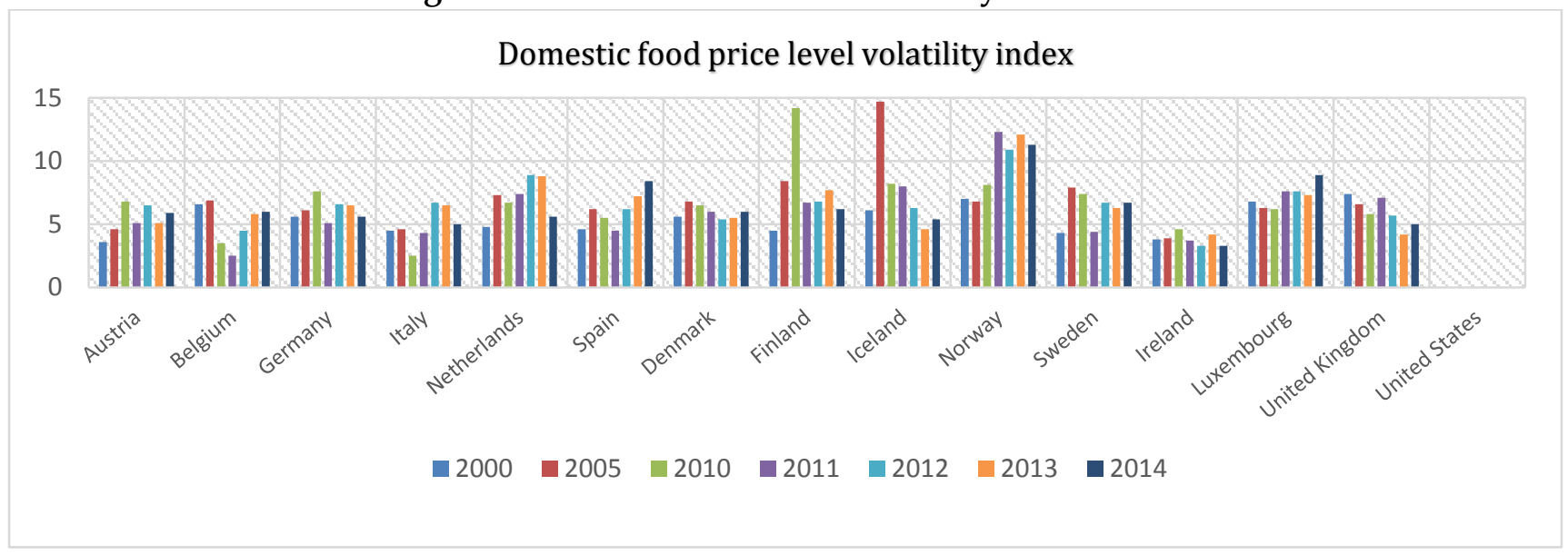

Source: Human Development Data, UNDP 2016.

Figure 4. Public Health Expenditure (Percent of GDP)

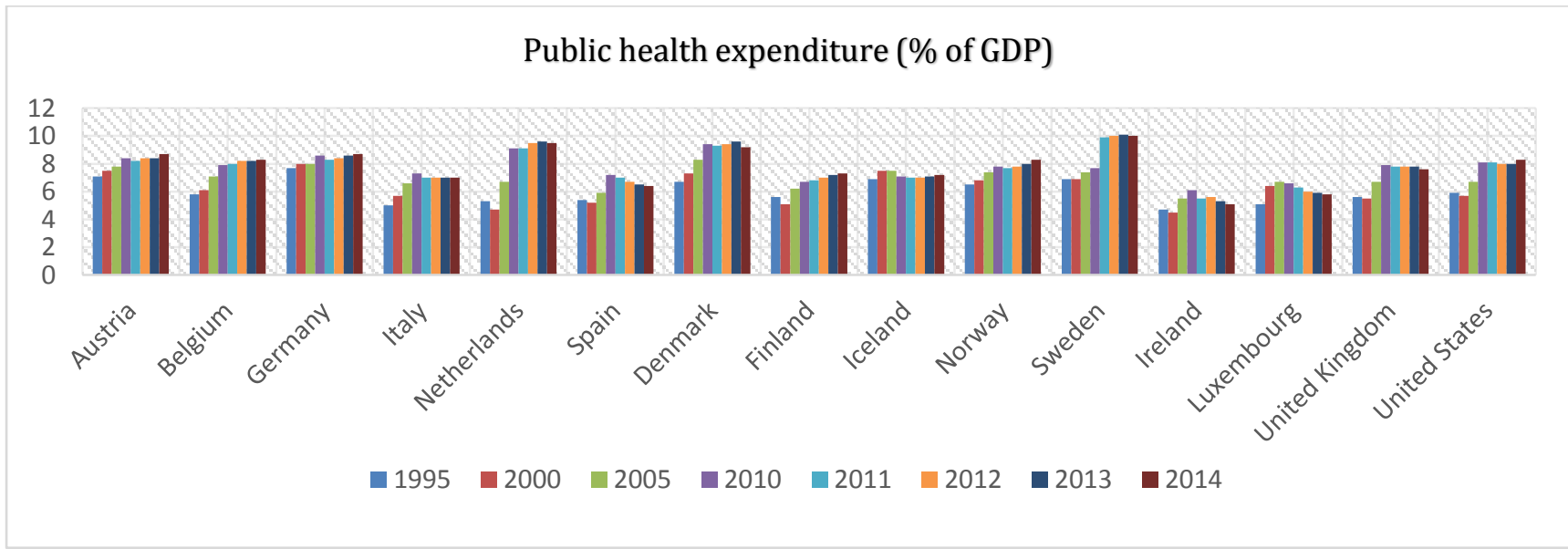

Source: Human Development Data, UNDP 2016 


\subsubsection{Health Performance}

In health performance between three different welfare state systems, we see data on the percentage of public health expenditure from GDP, life expectancy, and infant mortality rate. Based on public health expenditure on average social democratic welfare states come first, while conservative welfare states come second and liberal welfare states come last. Similar to economic data, although it comes second, conservative welfare states have fewer variances than social democratic welfare states. As expected liberal welfare states, which prefer to let the market provide the goods and services, have less government spending as we can see in the figure 4 .
The second indicator is life expectancy in years of people living in the state. As expected, social democratic and conservative welfare states have a similar average of life expectancy while liberal welfare states are coming last. We can expect this since there is some definite correlation between government spending on health with the quality of health variables such as life expectancy, and liberal welfare states are spent less in this case. The exciting thing about this data is higher variation in social democratic welfare state countries. Iceland, Sweden, and Norway doing exceptionally well (above the average of all states), while Denmark and Finland perform only on par with the average of the liberal welfare state. As we can see in the figure 5 .

Figure 5. Life Expectancy at Birth (Years)

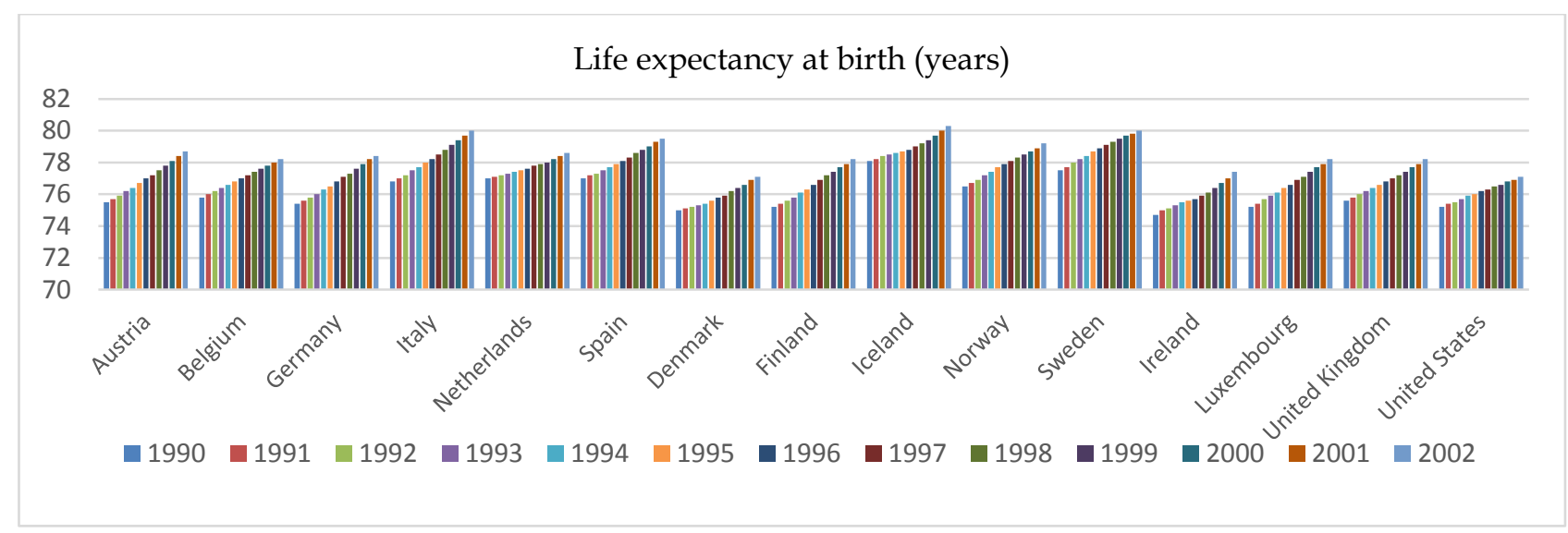

Source: Human Development Data, UNDP 2016

Figure 6. Infant Mortality Rate (Per 1000 Live Births)

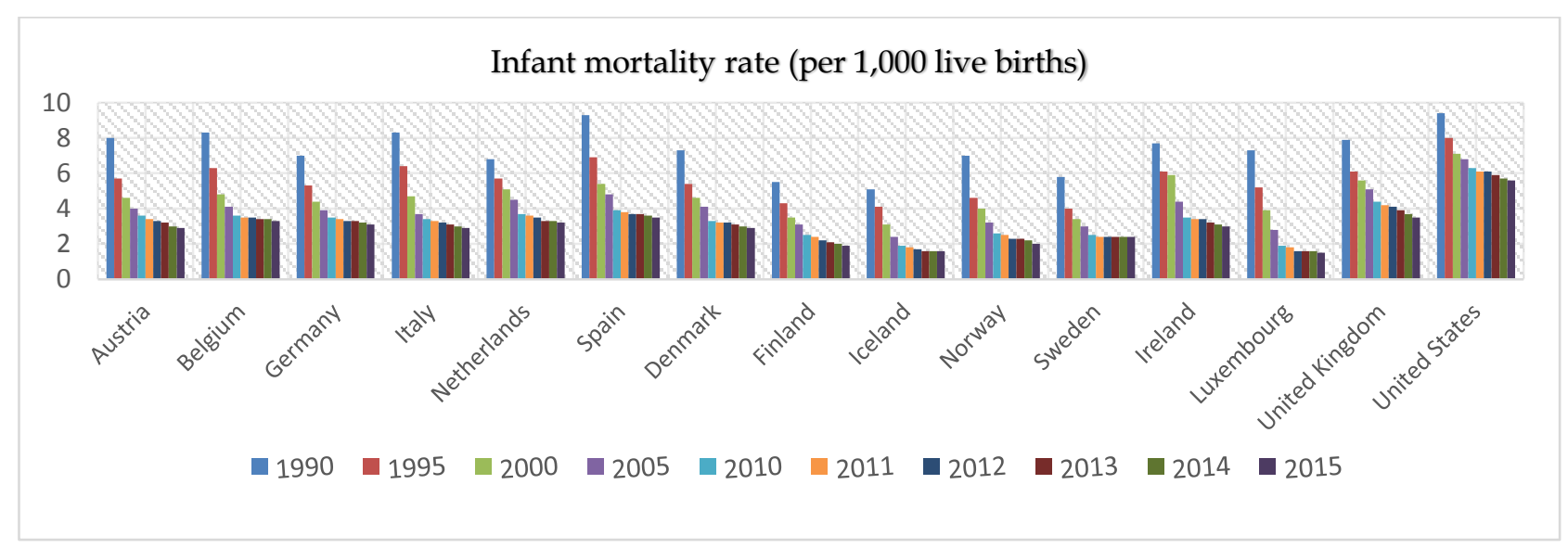

Source: Human Development Data, UNDP 2016 
The third indicator is infant mortality. Social democratic welfare states have the best achievement in this category, followed by conservative welfare states and liberal welfare states (except Luxembourg). Similar to previous data and indicators, the conservative welfare state has the less variance or each state identical to one another. The United States has the highest infant mortality rate among all the states as we can see in the figure 6 .

3.3.3 Performance on Accumulation of Human Capital
Accumulation of human capital performance seen by several indicators represent by education index and mean years of schooling. In education index data, on average there is not much difference between states in three different welfare state systems. Notable states that have low education index is Italy, Spain, and Luxembourg. All of the social democratic welfare states have high education index as we can see in the figure 7 .

Figure 7. Education Index

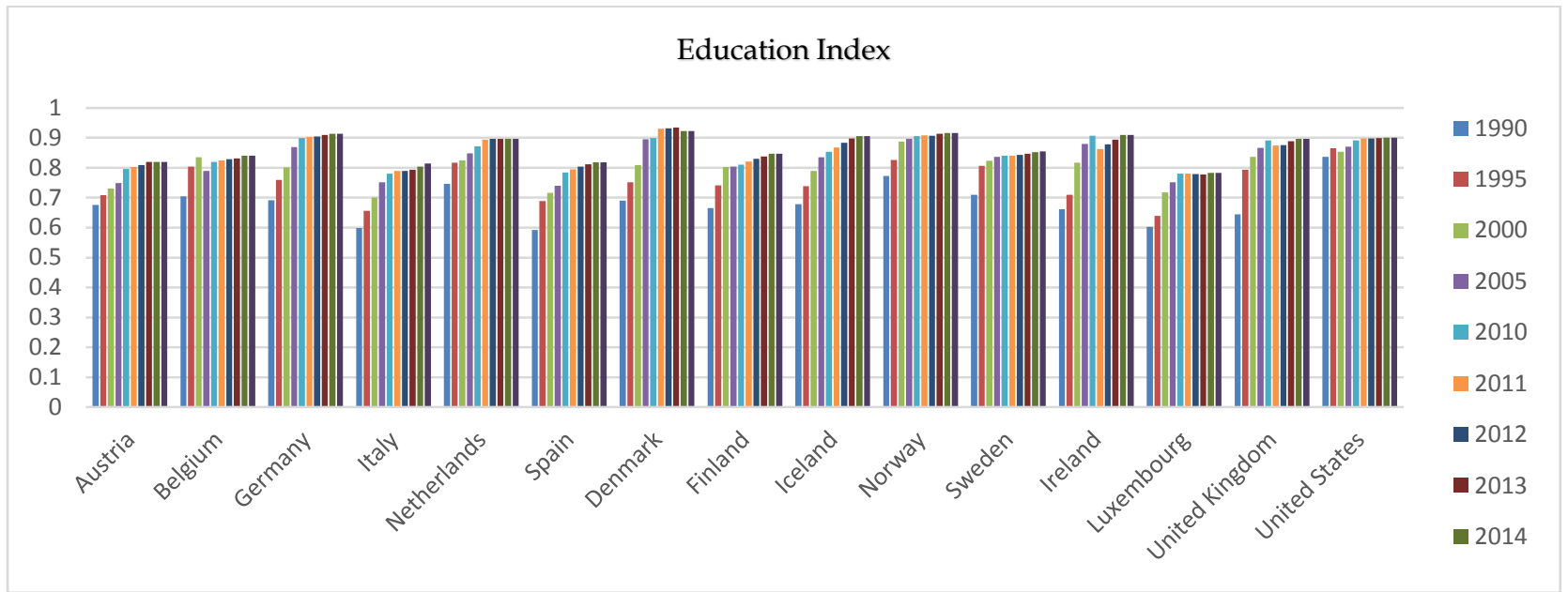

Source: Human Development Data, UNDP 2016

Figure 8. Mean Years of Schooling

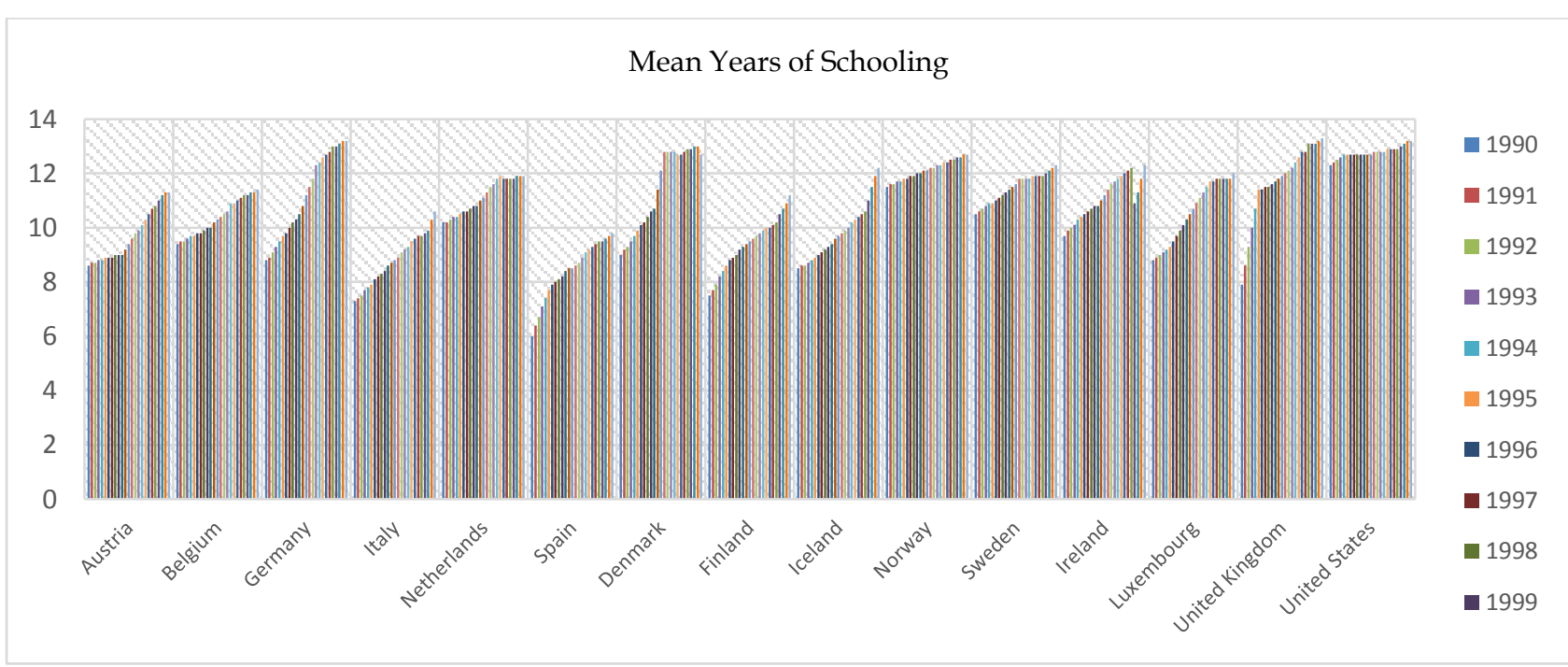

Source: Human Development Data, UNDP 2016 
Next education indicator is mean years of schooling. In this category, on average liberal welfare states perform above the average of any other systems, following by social democratic welfare states and conservative welfare states. We can expect this since, in the social democratic welfare state, most of the states have a similar education policy. Most of the states regardless the system gives free primary education up to high school, while a college or higher education is different in each state. However, if we see the growth of mean years of schooling, several states have higher growth than other states. States such as Germany, Denmark, and the United Kingdom, has the most top growth of mean years of schooling as we can see in figure 8 .

\subsection{Data Conclusion}

Looking at the data on three different welfare states (please see appendix) we can conclude that there is no exact direction how the type of welfare state system can increase the performance of the state. The state is facing a trade-off, for example between better economic performance and health performance. Another thing that we can draw from the data is conservative welfare state at least gives an average performance in many indicators with low variances. Thus it can be concluded that the safest decision for a state to do their conduct and roles as a state at least act like conservative welfare states.

However, only looking at the data, we cannot just conclude that type welfare state a state system can lead to increasing the general well-being. It needs further research and advanced statistical procedure to see the impact of the welfare state system on the economy. We have to make sure that the economic growth is exclusively from the system itself not from other variables such as political, people and demography, geographic location, and many more. Thus, advanced modeling of econometrics is needed in this matter.

\section{Comparative Analysis of Commons, Keynes and Esping-Andersen Welfare State}

Esping-Andersen (1990) classification of the welfare state: liberal, conservative and social democratic welfare state is similar to the definition and characteristics Commons and Keynes the role of the state. We can identify conservative welfare state as the most similar to Commons' definition of the role of the state. While the liberal state, kind of type state that has less government control and lean to laissez-faire spirit, is similar to Keynes the role of the state. Esping-Andersen in his paper using a degree of labor de-commodification and stratification to clarified welfare state system into three different systems. In this paper we will try to identify the connection between Commons and Keynes the Role of the State with Esping-Andersen classification of the welfare state by two approach: How far the state intervene the market (degree of market intervention) and how and what kind public goods the state is provided (degree of public goods provision).

\section{Indicators of Welfare State}

\subsection{The Degree of Market Intervention}

The depth and length of how far the state intervention is a good way connecting Commons and Keynes role of the state with EspingAndersen welfare state. In the liberal welfare state system, the state is limiting their intervention on the market. The state laid out the rules and regulation but only take action when needed. This system is pretty much similar to Keynes the role of the state. Keynes emphasis on limited state intervention and response. For example, the state needs to take action and intervene whenever a firm too big and has indication creates a monopoly. For example, when the market fails to provide the goods the consumer needs with affordable prices. Food prices are an excellent example in this case. If food prices are too high for people to buy, then the state can do an intervention by utilizing 
market operation or opening an import channel for the goods. However, Keynes emphasizes his explanation of the role of the state that the state should not intervene if it is unneeded. The state should not in the market selling food goods from the very beginning. Unneeded state intervention in the market could be causing more harm rather than gives benefit.

Conservative welfare state system has notable differences than the liberal welfare system on the approach how far the state should intervene the market. Conservative welfare state system encourages the state should play roles in the market early, as a mediator or arbitrator in the transaction, as a monitor to regulates working rules, and as a provider of undersupply goods and services in the market. An excellent example is in the conservative welfare state system countries, health is considered as primary needs. Thus, the demand for health, reflecting by the health insurance market, is heavily regulated in those countries. The reason for conducting this action is to make sure people have affordable health insurance and make sure there is no exploitation from the producer to consumer.

Commons emphasized this on the notion of bargaining transaction and fifth-party transaction. Commons (1924) argues that scarcity plus the idea how critical of the goods will create a potentially unbalance position of economic power which will lead to exploitation. Thus Commons postulates that the state should be present and involve in the market from the very early process of the transaction. As we can see here, Keynes the role of the state necessarily is liberal welfare state approach to intervene the market while Commons the role of the state is substantially how conservative approach the market to conducting an intervention.

\subsection{The Degree of Public Goods Provision}

Using public goods indicator is another way to connect the idea of Esping-Andersen of the welfare state to Commons and Keynes the role of the state. In the liberal welfare state sys- tem, the state is providing necessary public goods in some limited degree. The state is providing education and health to some extent and quality. However, to get a higher degree of education then people need to pay for themselves. United States case of education shows that several private schools also provide a better quality of education rather than public school. Although it is more expensive, these private schools tend to be more favorite choices for the student to get a degree.

Keynes elaborates this in his thought how the state should deliver public goods. Furthermore, Paul Samuelson (1954), a Keynesian economist, develops this idea by saying that private entrepreneurs even may not find it in their selfinterest to produce something, yet if the public values it and has enough to pay for it. For example, primary or general research activities which do not have a significant profit? ${ }^{7}$. The public maybe wishes to finance universities with their tax dollars. This kind of spending on research is what Keynes says about the role of the state in providing public goods. However to be noted that Keynes emphasize "when the market fail." Thus, if the market provides the goods, the state should not provide the goods or intervene in the market.

In a conservative-corporatist welfare state, the government provides the essential public goods to the extent more than liberal welfare state system offers. For example in education, most of the conservative welfare state provides primary and free education plus heavily subsidized higher education such as college. Thus we can see country such Netherland, Belgium and Germany have low-cost college or university. Commons argues the state should be involved in the market since the very beginning to create fair and just transaction. This state involvement can be seen in the countries adopted the system in their education sector. State involved in the

\footnotetext{
7 Basic or general research activities is different from applied research. Applied research is more applicable in the industry and could lead more substantial profit for the firm.
} 
education from the lowest level to the highest level. That is the reason the cost of tuition in most of these states is very cheap compared to another country.

Another critical difference between conservative welfare state systems from the liberal welfare state system is employee centered welfare benefit. Pensions and universal health insurance are employee rights. Commons essentially emphasize this role of the state. Commons labor law and social legislation substantially become the foundation for this program. United States Department of Labor acknowledges Commons as "Spiritual Father" of social security program because of his contribution to social security law principles in the US8.

\section{CONCLUSION}

We already discussed how Commons and Keynes have similarities and differences on the role of the state. We also explained how Commons set the foundation and principle of the welfare state. After that, we discussed how modern state differs one to another using Esping-Andersen type of classification. In the last part, we talked how Commons and Keynes the role of the state is necessarily a conservative and liberal welfare state respectively in EspingAndersen type of classification. We can conclude that, although Esping-Andersen is never mentioning Commons nor Keynes in his work on dividing the welfare state system, he gets an idea from those two thinkers. It is being justified by seeing the connection between Esping-Andersen classification and both Commons and Keynes the role of the state. Thus, it can be safe to say that both Commons and Keynes are influential to the development of the welfare state system.

It is worth to be noted that further research is needed to see the performance between three different welfare state systems. This paper

\footnotetext{
8 This word can be found in the Hall of Honor Inductee words in DoL website

https://www.dol.gov/general/aboutdol/hallofhonor/1989_c ommons
}

focuses on the history and foundation of the welfare state which refers to Keynes and John Commons as the earliest thought of welfare state system to Esping-Andersen as the newest welfare state system thought. As mentioned in section 5.4 (glance of empirical data), a comprehensive statistics and econometric method will be needed to see the real performance comparison between these three types of welfare state.

\section{REFERENCES}

Chandavarkar, A. (1911). Keynes and The Role of The State in Developing Countries. In D. Crabtree, \& A. Thirwall, Keynes and The Role of The State: The Tenth Keynes Seminar held at the University of Kent at Canterbury (126-175). Canterbury: St. Martin's Press.

Chase, J. D. (1986). John R. Commons and The Democratic State. Journal of Economic Issues, 20(3), 759-784.

Cochrane, A., Clarke, J., and Gewirtz, S. (2001). Comparing Welfare States. London: Sage.

Commons, J. R. (1924). Transaction. In J. R. Commons, Legal Foundation of Capitalism (65-142). New York: The Macmillan Company.

Commons, J. R. (1931). Institutional Economics. American Economic Review, 21(4), 648657.

Commons, J. R. (1963). Myself. New York: Macmillan.

Esping-Andersen, G. (1990). The Three Worlds of Welfare Capitalism. Cambridge: Polity Press.

Flint, C. (2012). Introduction to Geopolitics (2nd ed.). London: Routledge.

Gonce, R. A. (1971). John R. Commons's Legal Economic Theory. Journal of Economic Issues, 5(3), 80-95.

Harris, A. L. (1952). John R. Commons and the Welfare State. Southern Economic Association, 19(2), 222-233. 
Johnson, N. (1987). The Welfare State in Transition. Amherst: The University of Massachusetts Press.

Keynes, J. M. (2010). The End of Laissez-Faire. In J. M. Keynes, Essays in Persuasion. London: Palgrave Macmillan.

Marcuzzo, M. C. $(2017,11$ 28). Keynes and the Welfare State. Retrieved from http://www. ie. ufrj. br/eventos/seminarios/pesquisa/texto _02_12. pdf.(In Eng).

Medema, S. G., and Samuels, W. J. (2013). John R. Commons (1862 - 1945). In S. G. Medema, The history of economic thought: a reader (2nd ed., 684-690). New York: Routledge.

Peacock, A. (1991). Keynes and The Role of The State. In D. Crabtree, \& T. A.P., Keynes and The Role of The State: The Tenth Keynes Seminar held at the University of Kent at Canterbury, 1991 (3-32). Canterbury: St. Martin's Press.

Samuelson, P. (1954). The Pure Theory of Public Expenditure. The Review of Economics and Statistic, 36(4), 387-389.

Samuelson, P. (1964). Public Goods and Subscription TV: Correction of the Record. The Journal of Law and Economics, 7(1), 81-83.

Thabet, S. (2008). Keynes et Commons: histoires paralleles, destins croises. L'Economie politique, 2(38), 77-100. doi:10.3917/leco.038.0077

Waller, W. (2006). The Pragmatic State: Institutionalist Perspectives on the State. In S. Pressman, Alternative Theories of The State (684-690). New York: Routledge. 